\title{
Sosiaal-wetenskaplike kritiese eksegese van Nuwe-Testamentiese tekste - 'n voortgaande debat sonder einde
}

\author{
Andries G van Aarde ${ }^{1}$ \\ Fakulteit Teologie \\ Universiteit van Pretoria
}

\begin{abstract}
Social-scientific critical exegesis of New Testament

texts - an ongoing debate without end

The aim of this article is to describe the multifarious facets of socialscientific critical exegesis. It consists of a discussion of the theoretical epistemological premises behind anthropological models employed in the exegesis of Biblical tests. The article focuses in the second instance on work published by members of the Context Group. It subsequently discusses the socio-rhetorical approach and ideology criticism. The article concludes with the contribution made by hermeneutics of suspicion and cultural criticism. The article forms the third in a series of three that aims to introduce social-scientific critical exegesis of New Testament texts. The first article was of an introductory nature, the second explains some models and methods and the third discusses the critique against the approach as if it reflects positivism and concludes with an emphasis on cultural criticism as a hermeneutical challenge.
\end{abstract}

\section{INLEIDING}

In die tweede artikel in hierdie reeks van drie oor die sosiaal-wetenskaplike kritiese eksegese van Nuwe-Testamentiese tekste (Van Aarde 2007a:49-79;

\footnotetext{
${ }^{1}$ Andries $\mathrm{G}$ van Aarde is 'n emeritus professor in die Departement Nuwe-Testamentiese Wetenskap, Fakulteit Teologie, Universiteit van Pretoria. Hierdie artikel is die derde in 'n reeks. Met goedkeuring is die artikels verwerkings in Afrikaans van 'n Engelse opstel (met Stephan Joubert as mede-outeur) wat in 'n bundel oor eksegetiese metodologie en hermeneutiek in die reeks Guide to the New Testament, Volume III, onder redaksie van A B du Toit deur Protea Publishing House uitgegee word. Die eerste artikel is getiteld "Inleiding tot die sosiaal-wetenskaplike kritiese eksegese van Nuwe-Testamentiese tekste: Die metodologiese aanloop in die navorsingsgeskiedenis" (Van Aarde 2007a:41-79). Die tweede artikel is getiteld: "Die sosiaal-wetenskaplike kritiese eksegese van Nuwe-Testamentiese tekste: 'n Kritiese oorsig van die eerste resultate" (Van Aarde 2007b:515-542).
} 
2007b:515-542) het ons gesien dat eksponente hulle "sosiologiese ontleding" as eng verweef met die historiese kritiek sien (kyk o a Horrell 1999:15). Dit beteken egter nie 'n metodologiese eendersheid nie. Dikwels is dit juis teoloë wat met 'n historiese bewussyn eksegese beoefen, wat 'n besinning oor hulle teoretiese vooronderstellings vermy en nie daarvan hou om te erken dat hulle insigte vanuit die sosiologie en antropologie gebruik nie (vgl Horrell 1999:17). Sulke historiese studies word dan deur sosiaal-wetenskaplike kritiese eksegete gekritiseer omdat hulle in werklikheid hulle teoretiese vooronderstellings verdoesel terwyl dit wel implisiet aanwesig is. Hierdie artikel fokus op ondersoeke wat bewustelik van sosiale teorieë gebruik maak. ${ }^{2}$

By die Social Scientific Criticism Section van die Society of Biblical Literature Annual Meeting in Philadelphia (PA) op Sondag 20 November 2005 het David G Horrell (van die Universiteit van Exeter in die Verenigde Koninkryk) sy mening gelug oor toekomstige ontwikkelings rakende die sosiaal-wetenskaplike kritiese eksegese van Nuwe-Testamentiese tekste (kyk sy bydrae, getiteld "Social scientific interpretation thirty years on. Prospect (and retrospect)". Volgens Horrell sal dit - gegewe die invloed van hierdie benadering oor die algemeen en gegewe die wye verskeidenheid aspekte op die gebied van die kontemporêre sosiale en menswetenskap - moeiliker en moeiliker word om te kan sê wat onder "sosiaal-wetenskaplike" interpretasie tel of nie tel nie. Baie diverse paaie is oop vir toekomstige ondersoek. Buiten "postkoloniale" (en verwante) studies (kyk Van Aarde 2004b:1105-1125; kyk later), meld Horrell drie rigtings vir toekomstige ontwikkeling:

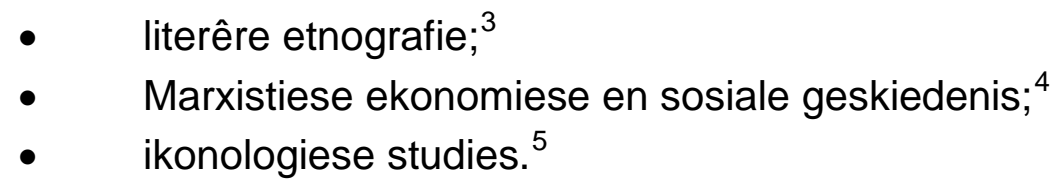

\footnotetext{
${ }^{2}$ Verskeie werke bestaan waar oorsigte van die verskillende benaderings tot die sosiaalwetenskaplike kritiese eksegese gebied word (bv D M May [1991] se Social scientific criticism of the New Testament: A bibliography. Macon, GA: Mercer University Press; John H Elliott [1993] se What is social scientific criticism? Minneapolis, MN: Fortress). Laasgenoemde werk bevat 'n gedetailleerde biografiese oorsig.

${ }^{3}$ Byvoorbeeld Louise J Lawrence se boeke (2003), An ethnography of the Gospel of Matthew. Tübingen: Mohr [WUNT 2.165.] en (2005), Reading with anthropology: Exhibiting New Testament religion. Carlisle,UK: Paternoster.

${ }^{4}$ Byvoorbeeld Justin J Meggit (1988). Paul, poverty and survival. Edinburgh: T\&T Clark; Steven J Friesen (2004). Poverty in Pauline studies: Beyond the so-called new consensus. Journal for the Study of the New Testament 26, 323-361; James G Crossley (2006). Why Christianity happened: A sociohistorical account of Christian origins (26-50 CE). Louisville, KY: Westminster John Knox Press.

${ }^{5}$ Byvoorbeeld Annette Weissenrieder, Fredirike Wendt \& Petra von Gemünden (eds) 2005. Picturing the New Testament: Studies in ancient visual images. Tübingen: Mohr. (WUNT 2.193.)
} 
In 'n vorige oorsigstudie het Horrell (1999:19-26) vyf fokusareas in die huidige debat onderskei wat hy ook as vooruitsigte vir toekomstige ontwikkeling sien. Myns insiens is hierdie areas meer verteenwoordigend van die huidige "sosiaal-wetenskaplike" eksegetiese studies as die rigtings wat Horrell in sy 2005 vooruitblik aangedui het. Sy vorige oorsigstudie sluit ook die "postkoloniale" en verwante studierigting in. Aangesien sy twee oorsigte ietwat oorvleuel, word slegs vier van hulle in hierdie artikel bespreek.

\section{TEORIEVORMING}

Die eerste fokusarea is metodologie as sodanig en veral die refleksie op die epistemologie van "etnografiese" antropoloë wat interpretatiewe modelle in hulle bestudering van Nuwe-Testamentiese studies gebruik (bv Garrett 1992; Craffert 1991; 1997; 2001:21-46). Werk op hierdie gebied is teoreties en abstrak. Dit gaan uit van die vertrekpunt dat kennis vanuit ' $n$ bepaalde sosiale konteks verkry en oorgedra word. Om van iets kennis te neem geskied met ander woorde nie buite 'n sosiale werklikheid om nie. Kennis self verteenwoordig dus 'n sosiale konstruk. Nadenke oor die sosiale aspek van epistemologie - dit wil sê die besinning oor die sosiale aard van kennis en die sosiale konteks en impak van die oorsprong (bronne), kriteria, moontlikhede en beperkings van kennis as sodanig - kan beskryf word as die sosiokognitiewe teoretiese vraagstelling of 'n bepaalde model 'n toepaslike draer is vir interpretasie en verduideliking van sekere data.

David Horrell (1999:20) wys daarop dat dit nie net eksegete en teoloë is wat met hierdie vraag worstel nie. Dit is 'n debat wat veral binne die sosiale wetenskappe self voorkom. Hy verwys byvoorbeeld na die voorkeur van die sosioloog Anthony Giddens (1984:xiii-xxxvii, 1-40) om eerder op spesifieke kontekste te wil fokus en sosiologiese verklarings van werklike gevalle in die praktyk van die lewe self te wil bied as om sosiologies te reflekteer oor veralgemenings. Die uitgangspunt van Max Weber (kyk Van Aarde 2007b:515-542.) wat met die begrip "ideële tipe" werk, word soms van so 'n veralgemenende sosiaal-wetenskaplike benadering verdink. Op die vakgebied van die teologie is dit veral praktiese teoloë wat die vraag vra of "praktiese teologie" per se "empiriese teologie" veronderstel. ${ }^{6}$ Spesifiek met betrekking

\footnotetext{
${ }^{6}$ Kyk veral die werk van die Nederlandse praktiese teoloog Johannes A van der Ven (kyk o a Van der Ven 1993:489; vgl ook Van der Ven 1990:11; 1993; 1994a, 1994b). Hieroor sê Immink (2003:184): "De vraag is niet of praktijkonderzoek tot het proprium van de praktische theologie hoort. Als praktijkwetenschap reflecteert de praktische theoloog op een praxisdomein en zij zal op enigerlei wijze die praktijk ook op een verantwoorde wijze in kaart brengen. Van der Ven heeft zelf op een indrukwekkende wijze kwantitatief onderzoek verricht en op die manier bijgedragen aan de ontwikkeling van de praktische theologie. Dit neem niet weg dat een praktijkwetenschap ook zonder empirisch onderzoek een bijdrage kan leveren aan de theorieontwikkeling van een praxisveld. Maar ook dan is een gedegen kennis van en betrokkenheid op het praxisdomein essentieel. Het is dus niet zo dat de praktische theologie als wetenschap samenvalt met de empirische theologie. Ook in internationaal opzicht is dat zeker niet het geval. Maar we kunnen wel constateren dat de empirisch theologie een sterke impuls aan de praktische theologie als praktijkwetenschap heeft gegeven. De vraag die wel nader onderzocht moet worden, is of het begrip 'empirisch' wel zo gelukkig is."
} 
tot sosiaal-wetenskaplike kritiese studies deur lede van die Context Group het Elisabeth Schüssler Fiorenza (2002:23-24) beswaar genaak dat hulle eksegese net 'n "sozio-rationalen Charakter" vertoon en nie ook hermeneuties suspisieus van aard is nie. Philip Esler (2005b:58) het egter die wyse waarop lede van die Context Group interpretasiemodelle gebruik, verdedig. Esler sê dat die idee dat gedetailleerde empiriese werk op een of ander manier meer wetenskaplik sou wees as teorievorming, 'n onverdedigbare ontkenning is van wat die hoofstroom in die antropologie vorm. Antropoloë probeer gewoonlik om op 'n deelnemende wyse kulture waar te neem en dan vanuit hulle waarneming breë "beginsels" daar te stel wat 'n wye toepassing kan hê. As 'n mens sulke etnografiesie navorsing van naderby bekyk, vind 'n mens dat eerstehandse observasie en die bespreking van die teoretiese dimensies van dit wat daaruit geleer is, met mekaar gekombineer is. Sulke etnografiesie werk koppel empiriese werk met teorievorming. Dit is moeilik om te sê waar die een aspek eindig en die ander begin. Volgens Esler sal 'n metafoor miskien help. As mens op 30,000 voet in 'n vliegtuig vlieg, kan mens slegs die groter kenmerke van die grond onder herken: mere, berge, vlaktes en dies meer. Wanneer neergedaal word om te land, verloor mens hierdie groot oorsigtelike prentjie, maar tog kan kleiner detail dan uitgeken word: individuele geboue, bome, motors en selfs mense. ' $n$ Meer volledige begrip van die landskap vereis die perspektiewe van beide 'n hoë en 'n lae hoogte. Sekere ondersoeke fokus egter meer op teorievorming, ander op die empiriese fasette en ander op beide. Nie een van die fokuspunte is minder wetenskaplik as die ander nie.

Teorievorming in wetenskaplike ondersoek binne die konteks van die "praktiese domein", soos Bybelwetenskap of Praktiese Teologie, wat nie die praktiese relevansie van teoretisering in ag neem nie, kan wel die gevaar loop op aan wetenskaplike kwaliteit in te boet. Uiteraard geld dit ook praktiese veldwerk wat teorievorming as onbelangrik beskou. Die werk van sosiaalwetenskaplik kritiese eksegete wat klem lê op die funksionaliteit van interpretatiewe modelle, soos die werk van lede van die Context Group, is 'n voorbeeld van wetenskap wat vauit die meer abstrakte teoretiese perspektief beoefen word. 'n Benadering wat heen en weer tussen teorievorming en veldwerk beweeg, ontbloot gewoonlik - in terme van die beeld van die vliegtuig - dat die prentjie van hoër op deur die data van laer vlakke ontken word). Dit is 'n leemte in empiriese ondersoeke om teorievorming af te skeep. Dieselfde geld van eksegese wat metodologie en die filosofiese epistemologie grondliggend daaraan buite reken laat of selfs as van geen belang ag nie. Dit is laasgenoemde tipe ondersoek wat neig om onwetenskaplik te wees. 


\section{DIE CIRCUM-MEDITERREENSE WÊRELD}

Die tweede area in sosiaal-wetenskaplike kritiese eksegese hou verband met die werk van die Context Group wat die aandag vestig op die sosiale dinamiek van die antieke Mediterreense wêreld. Dit verteenwoordig beide die modelgebaseerde metode en die werklike uitbeelding van die Mediterreense kultuur (Horrell 1999:21). John Elliott (1993:18-20) onderskei hierdie area van ondersoeke van sosiale realia wat beweer dat dit kenmerke van die antieke samelewing illustreer sonder enige inagneming van die ontleding, sintese, en verklaring van hierdie sosiale feite op enige sosiaal-wetenskaplike manier. In sosiaal-wetenskaplike kritiek, wat die kulturele milieu van die Nuwe Testament ondersoek, onderskei Elliott twee benaderings wat 'n doelbewuste gebruik van sosiale teorie en modelle verteenwoordig: een wat fokus op die sosiale en kulturele "scripts" wat sosiale interaksie beïnvloed of beperk en een wat die navorsing, teorie, en modelle van die sosiale wetenskappe gebruik in die ontleding van Bybelse tekste. Elliott se eie werk is 'n duidelike voorbeeld van laasgenoemde.

Volgens Elliott (1991:xix, xxii) is 'n sosiaal-wetenskaplike interpretasie van tekste daarop gemik om die teks se "betekenis-in-konteks" te bepaal ( $\mathrm{m}$ a $w$ die situasie van die teks) en sy sosiale retoriese strategie. Uit 'n sosiale retoriese perspektief is tekste eenhede van betekenisvolle diskoerse in ' $n$ mondelinge of geskrewe vorm. ' $n$ Teks word ontleed as 'n draer van kommunikasie waarvan die genre, struktuur, inhoud, temas, boodskap en doel gevorm word deur die kulturele en sosiale kragte van die sosiale stelsel en die spesifieke historiese milieu waarin dit geproduseer is en waarvoor dit 'n spesifieke respons daarstel.

'n Sosiaal-wetenskaplike ontleding van sosiale "scripts" wat sosiale interaksie beïnvloed sowel as beperk, en die "situasie" en "strategie" van Bybelse tekste, veronderstel ' $n$ onderskeid wat dikwels in die antropologie gemaak word, naamlik dié tussen emiese (emic) en etiese (etic) leserscenarios. Die begrip emiese is ontleen aan die woord "fonemiese" en die begrip etiese van "fonetiese". In taalteorie ondersoek fonemiek die dialek van hoe moedertaalsprekers praat. Dit is 'n soeke na die boorlinge se eie interne oogpunt. Fonetiek kyk na hoe 'n "eksterne" toeskouer dit beskou, en hoe mens behoort te praat volgens uitspraakmodelle. In sosiaalwetenskaplike studies verwys 'n ontleding vanuit 'n emiese perspektief (uit die boorlinge se oogpunt) na die beskrywing van die sosiale data volgens die interne kodes wat in ongeskrewe sosiale "scripts" of in literêre tekste geënkodeer is. Die etiese perspektief verwys na 'n eksterne verduideliking van die sosiale data vanuit die perspektief van die bestudeerder se oogpunt in 
terme van 'n bepaalde paradigma, teorie en model (kyk bespreking van terme in die vorige artikel; Van Aarde 2007b:526-529).

John Elliott (soos Gerd Theissen 1974, [1975] 1979, [1979] 1983) beskou sy "sosiologiese eksegese" as 'n direkte voortsetting van die aannames van die histories-kritiese paradigma. Bruce Malina, aan die ander kant, het bekendheid verwerf vir sy fokus op 'n sosiaal-wetenskaplike leserscenario. Malina onderskei tussen die pre-industriële "hoë konteks" van Bybelse tekste en die "lae konteks" van hedendaagse lesers (kyk bv Malina \& Rohrbaugh 1992:1-14). Laasgenoemde konteks vereis "verbruikersvriendelike" kommunikasie en agtergrondinligting word dus deur die leser benodig om te verstaan. In die "hoë konteks" van die Bybel word egter heelwat kennis veronderstel. Wanneer post-industriële mense pre-industriële tekste lees het hulle die hulp van sosiale modelle nodig wat vir hulle leserscenarios kan verskaf. Hierdie scenarios help dat lesers die outeurs van wie hulle sosiaal en tydsgewys verwyderd is, beter kan verstaan. Malina (met Rohrbaugh as mede-outeur) (1992:2-3) wys daarop dat dit algemeen is in Bybeluitleg om die tyds- en plekgebondenheid van die Bybel te herken. Ons weet dat die Nuwe Testament die produk is van 'n klein groep mense wat in die eerste eeu van die Chritelike era in die oostelike Mediterreense gebied gewoon het. Die afstand tussen die wêreld van daardie groep en ons eie word egter gewoonlik alleen in historiese terme bereken.

Baie navorsing is bestee om die historiese Bybelverhaal in moderne terme te vertolk. Sulke verklarings is egter nie voldoende om die posisie van die kontemporêre leser van die Bybel te verstaan nie. Onlangse sosiaalwetenskaplike studies van die Bybel het egter inderdaad begin herken dat die historiese afstand tussen die Bybel en ons sosiaal sowel as temporêr en konseptueel is. Die sosiale afstand het betrekking op radikale verskille in sosiale strukture, sosiale rolle, waardes, en algemene kulturele kenmerke. Die sosiale afstand verteenwoordig dus 'n fundamentele vervreemdheid. Die mense van die antieke tyd wat in agrariese samelewings van die Mediterreense wêreld geleef en geskryf het, het geleef in wat moderne antropoloë 'n "diffusiesfeer" noem. Die Mediterreense sosiale wêreld verteenwoordig 'n gebied met 'n stel algemene kulturele instellings wat oor lang periodes dieselfde gebly het. Dit is 'n gebied wat as 'n "kulturele kontinent" beskryf kan word. Bruce Malina verwys daarna as die circumMediterreense gebied. Dit is die gebied wat Nuwe-Testamentici interesseer. Dit verteenwoordig vyf millennia se gedeelde deelname in oorwinning, kolonialisme, en handel, tesame met familiaal gereëlde huwelike en 'n dorpsekonomie bestaande uit gemengde, kleinskaalse boerdery ingebed in 'n groot agrariese keiserryk. In hierdie circum-Mediterreense gebied is 'n stel 
gedeelde kulturele instellings geskep wat oor tyd bly bestaan het en tot vandag toe nog in 'n groot mate dieselfde is ( $\mathrm{vgl}$ ook Malina 1989; 1991; 1996:35-66).

\section{SOSIO-RETORIEK}

Volgens Horrell (1999:24) verteenwoordig die derde fokusarea in die sosiaalwetenskaplike kritiese eksegese ' $n$ belangrike nuwe rigting in Bybelwetenskap. Hierdie rigting kombineer literêre teorie met sosiaal-wetenskaplike kritiek. Horrell verwys spesifiek na die baanbrekerswerk van Vernon Robins (1996a, 1996b), wat die term "sosio-retoriese kritiek" geskep het (kyk veral sy boeke, The tapestry of early Christian discourse: Rhetoric, society and ideology. London: Routledge [1996a] en Exploring the texture of texts: A guide to socio-rhetorical interpretations. Valley Forge, PA: Trinity Press International [1996b]. Ook Norman R Petersen (1985) se ondersoek na die narratiewe aard van Paulus se brief aan Filemon (Rediscovering Paul: Philemon and the sociology of Paul's narrative world. Philadelphia, PA: Fortress) skep 'n verband tussen literêre en retoriese benaderings (kyk ook Petersen [1993] se werk oor die Johannes-evangelie, The Gospel of John and the sociology of light: Language and characterization in the Fourth Gospel. Valley Forge, PA: Trinity Press International). David Rhoads (1992:135-161) se inleidende bydrae, "Social criticism: Crossing boundaries" en Pierre-Ives Brandt (2005:135-147) se artikel, "Erzählung und Identitätsbildung: Die Spiegelfunktion von Mk 12,1-12 in der Konstruktion der Identität Jesu", toon 'n soortgelyke "sosio-retoriese" oorweging.

Navorsing op hierdie gebied is ook aan die Universiteit van Pretoria gedoen. 'n Aantal doktorale proefskrifte onder die studieleiding van Andries van Aarde het narratologie en sosiaal-wetenskaplike kritiek gekombineer (kyk Piet van Staden 1991; Ernest van Eck [1994] 1995; Evert Jan Vledder [1991] 1997; Yolanda Dreyer 2000; Dieter Reinstorf 2002; en In-Cheol Shin 2004).

\section{IDEOLOGIEKRITIEK}

Die vierde area van sosiaal-wetenskaplike kritiese eksegetiese studies wat Horrell (1999:22-24) identifiseer, is "ideologiekritiek". Hier het Horrell die werk van feministe en bevrydingsteoloë wat Marxistiese en kritiese sosiale teorieë gebruik, in gedagte. Ons kan hierby "kritiese eksegese" uit die perspektief van 'n hermeneutiek van suspisie voeg, waarna ook verwys word as "betrokke hermeneutiek" (engaged hermeneutics). Voorbeelde is die "exiliese/diaspora"hermeneutiek wat deur Segovia (1998:49-65; 2000a; 2000b:11-34; 2000c:59- 
83), asook postkoloniale hermeneutiek wat deur Musa W Dube (1998: 224245) toegepas is. ${ }^{7}$

'n Hermeneutiek van suspisie fokus op die sosiale toestande van die mense waarna 'n teks verwys asook van diegene wat die teks lees en aan die teks blootgestel word. Die term "sosiale toestande" ("kondisie") verwys na daardie sosiale faktore wat ' $n$ individu of groep beïnvloed. Tradisioneel word dit "sosialisering" genoem en dit verwys na ervarings en persepsies ( $m$ a w mense se sosiale en simboliese universums) wat die raamwerk vir mense se rasionaliteit en realiteitsblik vorm. Dit sluit faktore in soos geslag (gender), seksuele oriëntasie, ouderdom, etnisiteit, klas, status, rolle, roeping, nasionaliteit, sosiale groepe, politieke, religieuse en kulturele affiliasies asook taal. Al hierdie faktore maak daartoe ' $n$ bydrae dat menings en betekenisse wat mense aan dinge of gebeure heg, verskil.

Gender-hermeneutiek illustreer, byvoorbeeld, hoe 'n persoon se "sosiale kondisie" lei tot vooroordeel wat weer die teologies onverdedigbare verskynsel van homofobie tot gevolg het (kyk Dreyer [2006a, 2006b]. Genderhermeneutiek is uitgebrei om "queer theory" in te sluit. ' $n$ Voorbeeld van hoe 'n "queer"-teoretikus Bybelse tekste benader, word deur onder andere Schneider (2000:208) gegee. Volgens Schneider sal 'n "queer"-teoretikus onder andere die tersaaklike Bybelekste met 'n oënskynlike verbod op homoseksuele praktyke ondersoek, maar eintlik meer geïnteresseerd wees in die verskynsel dat daar mense is wat hierdie tekste as ' $n$ verbod waarneem. Die fokus van die ondersoek is dus op die waargenome noodwendigheid en die magsdinamiek wat hierdie "noodwendigheid" ontbloot. Die eksegetiese vraag word dus nie gelei deur ' $n$ interesse in kultureel-godsdienstige morele aansprake wat die teks moontlik op lesers kan maak nie. "Queer"-teorie se radikale historisisme verwerp dan ook inderdaad enige aansprake op deontologiese outoriteit en wys hierdie aansprake uit as 'n fabrisering en ontplooiing van mag. So gesien, sluit "queer"-teorie aan by die teologiese debat oor die bronne en outoriteit van tradisies wat sosiale norme en menslike identiteite omskryf in terme van sonde, verlossing, goed en kwaad, veral

\footnotetext{
${ }^{7}$ In sy 2005-toekomsblik op toekomstige ondersoeke op die gebied van die "sosiaalwetenskaplike" studies van die Nuwe Testament noem David Horrell die volgende publikasies verteenwoordigend van "postkoloniale (en verwante) studies": James C Scott 1990. Domination and the arts of resistance. New Haven, Conn: Yale University Press; Homi Bhaba 1994. The location of culture. London: Routledge; Harry O Maier 2005. A sly civility: Colossians and Empire. Journal for the Study of the New Testament 27, 323-349; Warren Carter 2004. Going all the way? Honoring the Emperor and sacrificing wives and slaves in 1 Peter 2.13-3.6, in Levine, A-J \& Robbins, M M (eds), A feminist companion to the Catholic Epistles and Hebrews, 14-33. London:T\&T Clark (vir 'n meer volledige oorsig, kyk Andries van Aarde 2004b. Some thoughts on post-colonial hermeneutics and New Testament scholarship. Openbare lesing as besoekende professor aan die Evangelical Theological Seminary in Kaïro, Egipte, op 16 November 2004).
} 
aangesien hierdie kategorieë uitgedruk word in terme van gender en ras (Schneider 2000:209).

Volgens Horrell (1999:23) stem die voorstaanders van sulke ideologies-kritiese studies nie daaroor saam of die vroeë Christelike boodskap die sosiale orde van die tyd uitgedaag het en of dit dit bloot onderhou het nie. Wat belangrik is, is dat hierdie kritiese sosiologiese vrae prominent op die agenda van studies oor die Nuwe Testament geplaas is. 'n Mens kan daarom verwag dat verdere debat sal poog om nie alleen die reeks moontlike antwoorde op hierdie tipe vrae duidelik te maak nie, maar ook die wyses waarop teorieë in die tradisies van die kritiese neo-Marxistiese sosiale teorie (soos bv dié in die "Frankfurt Skool) ${ }^{8}$ gebruik kan word om histories geloofwaardige radikale perspektiewe op die vroeë kerk te ontwikkel.

Postkoloniale interpretasies van Nuwe-Testamentiese tekste kan as 'n sodanige geval gesien word (kyk Van Aarde 2004b). Tog skep sulke studies 'n probleem vir diegene wat antieke literatuur bestudeer. Postkoloniale hermeneutiek is kruiskulturele studies wat ook op die dinamiek van beide Bybelse kulture as die kulture van die postkoloniale derde wêreld fokus (kyk o a Sugirtharajah 1998a, 1998b, 1998c, 1999; Segovia 1998, 2002a, 2002b, 2002c; Punt 2001, 2002a, 2002b, 2002c). Die hermeneutiese probleem van etnosentrisme is in sulke studies 'n werklike gevaar. Etnosentrisme is 'n hermeneutiese dwaling om nie genoegsaam te onderskei tussen die verskille tussen kulture op 'n sinchroniese en 'n diachroniese vlak nie. Hedendaagse kulture is nie noodwendig op dieselfde wyse gekonstitueer as dié in die antieke Mediterreense wêreld nie. In die lig van Bruce Malina se "reading scenario"-model behoort postkoloniale eksegetiese studies in ag neem dat die Nuwe Testament meer as twee duisend jaar gelede ontstaan het in 'n homogene agrariese samelewing, terwyl die mense van die postkoloniale wêreld 'n aantal aspekte van die geïndustrialiseerde wêreldorp ("global village") in hulle samelewings opgeneem het. Daar is dis 'n groot verskil tussen die postkolonale konteks van die hedendaagse wêreld en die konteks van die Bybelse tyd, hoewel laasgenoemde ook as "postkoloniaal" beskryf kan word as gevolg van die uitwerking wat imperiale magte op mense op die grondvlak van die samelewing gehad het. Eksegete vandag kan nie die Bybel "wetenskaplik" interpreteer asof die industriële rewolusie niks aan ons patrone van sosiale persepsie verander het nie (Holmberg 1990:133; vgl Rohrbauch 1987:113).

Vir hierdie rede kan die insigte van sosiaal-wetenskaplike Bybelkritiek, wat doelbewus poog om etnosentrisme te vermy, bruikbaar in 'n metodologie geïntegreer word wat korreleeer met postmoderne teorieë en postkoloniale

\footnotetext{
${ }^{8}$ Kyk o a Hoefnagels, H [1974] 1976. Kritische sociologie: Inleiding tot het sociologisch denken der "Frankfurter Schule". 2e druk. Alphen aan den Rijn: Samson Uitgeverij. (Sociaal Politieke Verkenningen.)
} 
interpretasiemodelle. 'n Voorbeeld is die werk van die "sosiaal-wetenskaplike" eksegeet, Dennis Duling (2005), oor die invloed van die Romeinse Ryk op Palestynse gemeenskappe, soos dit uitgebeeld word in die Matteusevangelie. Duling gebruik die antropoloog Gerhard Lenski (1966, 1970 [1970], 1991, [1970] 1995) se teorie oor die opkoms van keiserryke.

\section{6. 'N KRITIESE DEBAT SONDER EINDE}

Hoewel sosiaal-wetenskaplike kritiek 'n ryk en diverse studieveld met baie meningsverskille verteenwoordig, is die bruikbaarheid daarvan vir die Bybelwetenskap nou reeds oor dekades bevestig, Tog kan die belangrikheid om verder metodologies oor die epistemologie ten grondslag daarvan nie onderbeklemtoon word nie. Ook onder klassici wat op kruis-kulturele antropologie steun, is daar verskil van opinie oor epistemologie en metodologie. Byvoorbeeld, volgens Paul Cartledge (in Horrell 1999:20), is daar aan die kant diegene wat glo dat dit moontlik en wenslik is om ten opsigte van die sosiale dinamiek van mense en groepe in die hele moderne Griekeland veralgemenende ondersoeke te loods en soms, nog breër, die Mediterreense wêreld as sodanig daarby in te sluit. Sulke veralgemeende vergelykende data kan volgens Cartledge gebruik word om die gapings in die primêre data oor die antieke tyd aan te vul en te interpreteer. Aan die ander kant is daar diegene onder klassici wat meen dat sulke vergelykings eintlik hoofsaaklik net gebruik behoort te word om fundamentele kulturele verskille uit te lig, sodat heterogene kulture nie as homogeen voorgestel en navorsingsgapings in die primêre bronne oor hierdie kulture met veralgemenings aan gevul word nie.

Volgens Horrell (1999:21) kan 'n ondersoeker kwalik verwag - en myns insiens is dit ook nie wenslik nie - dat die huidige diversiteit van metodes en praktyk in die sosiaal-wetenskaplike kritiese eksegese gou sal verdwyn. Dit is wel belangrik dat die teoretiese vraagstukke wat onderliggend is aan die verskeidenheid benaderings, krities ondersoek en gedebateer sal word. So kan duidelikheid gekry word oor wat die kwessies is wat onder dispuut is, sodat nuwe navorsingsrigtings ontgin, verfyn en herformuleer kan word.

'n Belangrike vraagstuk in die hedendaagse debat is of sosiaalwetenskaplike kritiese eksegese, epistemologies gesien, aan positivisme skuldig is. Ons het vroeër daarop gewys dat iemand soos Elisabeth Schüssler Fiorenza (2002:23-24) van mening is dat dit wel die geval kan wees as sosiaal-wetenskaplike kritiese eksegete nie konkrete ideologiese belange met behulp van 'n hermeneutiek van suspisie aan die kaak stel nie. Sonder 'n kultuur-kritiese hermeneutiek (kyk later in laaste afdeling van hierdie artikel) kan die gebruik van sosiaal-wetenskaplke modelle vir die ontleding van 
Bybelse data neerkom op 'n predeterminerende voorskrif dat 'n teks op ' $n$ spesifieke manier verstaan móét word en glad nie op 'n ander nie. Hierdie tipe arogansie het vroeër redelik algemeen in wetenskaplike kringe voorgekom en veral teoloë en eksegete het hulle daaraan skuldig gemaak. Dit het soms 'n "onskuldige" patroon aangeneem deurdat geargumenteer is dat ' $n$ probleemstelling met ' $n$ hipotese benader is wat dan deur die wetenskaplike ondersoek geverifieer is. Hierdie tipe epistemologie is as induktief beskryf en het na bewering groter wetenskaplike gewig gedra as 'n deduktiewe benadering wat onder die vaandel van sogenaamde "objektiewe wetenskap" gevaar het. In werklikheid het die vooringenome hipotese in induktiewe redenasies op 'n rigiede wyse gefunksioneer omdat dit die gang van die ondersoek self, die seleksie van die data vir analise, asook die uitslag van die resulate van die ondersoek deur middel van die vooringenome hipotese gepredetermineer het. Die gebruikmaking van 'n sosiaal-wetenskaplike kritiese model in eksegese kan, epistemologies gesien, net soos 'n hipotese funksioneer. So 'n hegemoniese benadering tot wetenskap kom op arogansie en positiwisme neer (vgl Horrell 1999:19 wat na die kritiek van o a S Garrett 1992:93 en D B Martin 1993:107-110 verwys).

Lede van die Context Group ontken egter dat hulle gebruik van 'n toepaslike stel sosiaal-wetenskaplike modelle neerkom op positivistiese induktiewe eksegetiese beredenering. Philip Esler (1995a:4-8; 1998), byvoorbeeld, sien sosiaal-wetenskaplike kritiek as heuristies en nie as voorskriftelik nie. John H Elliott (1993), wat die insigte van die feministiese linguïs Linda Woodson (1979:1) gebruik, beskryf sosiaal-wetenskaplike kritiek as 'n "abduktiewe" of "retroduktiewe" epistemologiese benadering en nie as "induktief-positivisties" nie. Volgens Elliott (1993:48) behels sosiaalwetenskaplike kritiek 'n logiese proses wat nog eksklusief deduktief is (vanaf 'n model na die tersaaklike data), nog induktief (vanaf die data na die hipotese) maar sluit albei in. So 'n heen-en-weer beweging vorm 'n wetenskaplike prosedure wat beskryf word as abduksie. Abduksie - ook genoem "retroduksie" - is 'n logiese proses van die wetenskaplike ontdekkingsprosedure waarvolgens die ondersoeker te werk gaan deur vanaf die tersaaklike data af na 'n moontlike, relevante en funksionele hipotese toe te beweeg. Dit beteken dus dat dat in 'n wetenskaplike ondersoek binne 'n praktiese domein - soos eksegese of empiriese veldwerk - die data self wat ondersoek word, die ondersoeker sal lei om vrae na relevante en funksionele teorieë, modelle, perspektiewe en metodes in die sosiale en menswetenskappe te vra, toepaslikes te identifiseer, navorsingsleemtes ten opsigte van sekeres te herken en, indien nodig, wysigings in teorie, model, perspektief en metode aan te bring. Die "hipotese" determineer dus nie die ondersoek of die 
resulaat nie. Inteendeel, 'n abduktiewe tipe argumentvoering behels die heenen-weer beweeg en kritiese bevraagtekening van navorsingsvoorstelle waarna Linda Woodson as intuition verwys. In so 'n proses kan die verband van data met mekaar deur middel van 'n hipotese (=model) verklaar word, die geldigheid van die verklaring kan gekontroleer word deur dit te toets met addisionele data en die verklaring - maar ook die hipotese self - kan aangepas word, indien nodig. Op hierdie wyse word finaliteit en gearriveerdheid in wetenskaplike ondersoek onmoontlik gemaak. Die wetenskaplike beleef ook nie ongemak met onsekerhede in kennis of wysiging van kennis nie.

Deur sosiaal-wetenskaplike kritiese eksegese op 'n abduktiewe epistemologiese wyse aan te wend, bly die ontleding en verduideliking van Bybelse data gevolglik oop vir die moontlikheid dat die eksegeet se aangenome teorie en perspektief gefalsifieer kan word en derhalwe aangepas kan word. Hierdie sensitiwiteit om die empiriese eensydigheid van beide die deduktiewe en die induktiewe benaderings in die sosiale wetenskappe te vermy, kan toegeskryf word aan die insigte van die negentiende-eeuse wetenskaplike Charles Peirce (1932:53-54). Dit is Peirce se nie-positivistiese benadering wat in epistemologiese studies bekendstaan as "abduksie" (kyk Fann 1970:5-10; Reilly 1970:30-38; Ochs 1998:114-115). Vanaf 'n retoriese perspektief beskryf die Nuwe-Testamentikus Robert Brawley hierdie soort sosiale redenasie as 'n "betwisting van konstrukte van realiteite". Volgens Brawley vind bevraagtekening in wetenskaplike ondersoek plaas omdat elemente wat oënskynlik geen verband met mekaar toon nie, in die ondersoekproses op 'n verbeeldingryke wyse met mekaar geassosieer word. Wat gebeur, is dat die elemente met mekaar gekoppel word soos wanneer daar in 'n metafoor twee sake met mekaar vergelyk word. Abduksie funksioneer daarom soos 'n vars metafoor, want iets nuuts word geskep deurdat iets wat konvensioneel is, geassosieer word met iets anders konvensioneel, maar die assosiasie van die twee elemente omskep die konvensionele in "nuwe" onkonvensionele perspektiewe. ${ }^{9}$ Wetenskap beleef dus progressie as gevolg van innovasie. Uit bestaande navorsingresultate word nuwe verbande geskep wat leemtes in die bestaande vul. Derhalwe begin abduktiewe redenasie met 'n skok, 'n uitdaging, disoriëntasie. Die skok

\footnotetext{
${ }^{9}$ In die retoriek is dit wat konvensioneel verwant is, tipies. Maar deur dit wat onkonvensioneel is, met mekaar in verband te bring, is om 'n tropiese relasie te skep.
} 
breek die raamwerk van konvensionele denke uitmekaar en konfronteer lesers met 'n nuwe manier om die werklikheid te konstrueer. ${ }^{10}$

In die lig van die toepassing van 'n verskeidenheid sosiaalwetenskaplike modelle kan mens sonder vrees van teenspraak sê dat hedendaagse Bybelwetenskap, soos ook ander postmoderne wetenskaplike refleksie, multidissiplinêr en interdissiplinêr is. Die gebruik van narratologiese en sosiologiese teorieë en modelle in eksegese het die nuwe vraagstukke in hedendaagse Bybelwetenskap uitgelig. Binne hierdie paradigma het sosiaalwetenskaplike kritiek 'n aantal tot nog toe onverkende aspekte van die kulturele agtergrond van die Nuwe Testament na vore gebring. Bepaalde impasse in die huidige navorsing word opnuut ondersoek. Vroeëre debatte is weer heropen in die hoop dat hulle kan help om verstaanbare, geloofwaardige verduidelikings van die probleme van ons eie tyd te verskaf. 'n Toenemende bewustheid van etnosentrisme is miskien een van die hoofvoordele van sosiaal-wetenskaplike kritiese eksegese.

Hierdie bewustheid het etiese implikasies vir die Christelike praktyk. Interprestasies van die Nuwe Testament was nie altyd sensitief genoeg ten opsigte van die historiese afstand tussen die eerste en die twintigste eeu nie. Ekonomiese en politieke kragte wat onderliggend is aan moderne sosiale spanning (soos digotomieë ten opsigte van slaaf-en-vry; man-en-vrou, heteroseksueel-homoseksueel, inklusief-eksklusief, ryk-en-arm, ens) word dikwels toegeskryf aan toestande wat waarskynlik ook in Jesus se wêreld of dié van die vroeë Jesus-bewegings teenwoordig was. Met ander woorde, antieke pre-industriële dokumente word uit die oogpunt van hedendaagse samelewingstrukture interpreteer. Dit impliseer etnosentrisme en reduksionisme.

Etnosentrisme is die verskynsel dat die kulturele afstand tussen antieke en moderne samelewings, en tussen bepaalde kulture in 'n gegewe periode, nie voldoende in ag geneem word nie. Etnosentrisme kom dus neer op die fusie van "onversoenbare" kulturele verskille. Wanneer dit in eksegetiese ondersoeke gebeur, het ons nie met 'n verantwoordelike kruis-kulturele onderneming te doen nie, maar met 'n hegemoniese redusering van die "ander" tot die eie bekende. Die eksegetiese verleiding is dat daar gemeen kan word dat dat die "ander", dit wil sê die "onbekende", in terme van dit wat

\footnotetext{
${ }^{10}$ Die gebruik van Max Weber ([1947] 1968a, 1949, 1962, 1968b) se teorie van die "ideële tipe" (kyk vorige artikel; Van Aarde 2007b:522-523, 535 nota 5) deur Andries van Aarde (2001:29-30) in sy historiese Jesus-navorsing is 'n voorbeeld van so 'n doelbewuste toepassing van die sosiaal-wetenskaplike "model-gebaseerde" benadering (kyk ook sy student Jonanda Groenewald (2005) se doktorale proefskrif vir 'n "abduktiewe" toepassing van die sosiaal-wetenskaplike modelle van "veranderde geestestoestande" "en antisamelewingstaal-gebruik").
} 
bekend is, verstaan word, terwyl in werklikheid die "ander" omgebuig word na die bekende en die eie daarvan verloor word. Daarom is reduksionisme 'n vorm van misplaasde konkreetheid.

Dit kom verder ook voor wanneer 'n breë spektrum verweefde sosioreligieuse verskynsels uit die antieke verklaar word vanuit ' $n$ perspektief wat gebore is in 'n moderne konteks en daarom gebaseer is op die raamwerk van die dinamiek van een of twee sosiale instellings soos moderne ekonomie en politiek. Dit kom onder andere voor by ideologie-kritici wat in hulle eksegetiese programme primêr die emansipasie van hedendaagse polities-onderdruktes en ekonomies-benadeeldes in die oog het. Voorstaanders van so 'n benadering word dikwels onder histories-materialistiese interpreteerders van die Bybel gevind. So, byvoorbeeld, word verwysings in die (pre-industriële) Bybel na 'n verwydering van hulpbronne en ostrasisme (met ander woorde, ' $n$ uitsluiting van algemene voorregte en sosiale aanvaarding) toegeskryf aan ekonomiese en politieke ideologieë wat Karl Marx in die moderne industriële samelewing herken het. Sosiaal-wetenskaplike kritiek maak ons egter bewus van nie net kruis-kulturele eendershede nie, maar ook van verskille tussen die onderskeie kosmologieë, ideologieë, en mitologieë. Dit verminder egter nie die appèl wat die hermeneutiek van suspisie op die sosiaal-wetenskaplike kritiese eksegeet maak nie.

\section{KULTUURKRITIEK AS HERMENEUTIESE IMPERATIEF}

In die eerste artikel van die onderhawige reeks van drie oor die sosiaalwetenskaplike kritiese ekegese het ons daarop gewys dat dat die innoverende studies op die gebied van "sosiologiese eksegese" geïnspireer was deur die werk van die sosioloog Peter Berger (kyk Van Aarde 2007a:515-542). Dit was besonderlik Berger wat ingesien het dat die dinamiek van sosiale realiteite dialekties deur ' $n$ "simboliese wêreld" beïnvloed word. Berger het na hierdie sacred canopy verwys as die "heilige koepel" wat mense se sosiale idees, insluitende dié van teoloë en eksegete, onbewustelik vanuit 'n transendentale domein beïnvloed. Dit is egter ook dieselfde Peter Berger wat ' $n$ beroep gedoen het op Christene in die Westerse wêreld om te waak teen "valse geloof" (bad faith) ${ }^{11}$ Peter Berger, wat in 1929 in Wene gebore is, is tans die direkteur van die Boston Universiteit se Institute on Religion and World Affairs. In sy 2004 boek, Questions of faith: A skeptical affirmation of Christianity, neem hy ' $n$ kritiese houding in jeens godsdienstige tradisie in die sin dat hy met hierdie tradisie voortgaan en tegelykertyd verskeie aspekte daarvan

\footnotetext{
${ }^{11}$ Kyk veral Berger (1961) se boek, The noise of solemn assemblies: Christian commitment and the religious establishment in America, veral bls 39-57 (vgl die artikel deur Andries van Aarde [2005], Cultural criticism as an imperative for Christians, in HTS 61/3 683-708).
} 
verwerp. In sy eie woorde kan sy argument beskryf word as beide "skeptisisme" en "affirmasie" - en dit verteenwoordig nie 'n oksimoron nie. Hy sê dat sy argument is skepties in die sin dat dit nie geloof vooronderstel nie en dat dit nie noodwendig 'n gebondenheid het met enige van die outoritêre geloofstradisies van die kerk nie - hetsy die Rooms-Katolieke idee dat die kerk as instituut onfeilbaar sou wees, die ortodokse idee by beide Katolieke en Protestante dat die Heilige Skrif onfeilbaar sou wees, of die evangelikaalse idee dat 'n persoonlike spirituele ervaring van 'n individu onbetwisbaar outoriteit by ander moet geniet. Peter Berger sien homself nie - in my terme as op 'n "foundationalist" wyse ${ }^{12}$ of in bekende Hervormde terminologie, in terme van "konfessionele teologie"13 - onvoorwaardelik gebind aan die fundamentele religieuse tradisies wat in die kerkgeskiedenis in belydenisvorm neerslag gevind het nie. Desnieteenstaande, sê hy, vind sy geloof tog weer grond in 'n affirmasie van die Christelike geloof, hoe heterodoks ook al (Berger 2004:vii-viii).

Uit Berger se oogpunt het kultuur hoofsaaklik te doen met denke, houdings, emosie, waardes, lewenspatrone en geloof op 'n abstrakte vlak. Met ander woorde, kultuur is daardie dimensie wat oorbly wanneer alle empiriese menslike gedrag - hoe onmoontlik dit ook al klink - opgeskort word. Met ander woorde, presies dit wat ons tradisioneel meen kultuur is, word op paradoksale wyse opsy gesit om uit te kom wat in werklikheid kultuur is! Waarby dan uitgekom word, is om op die transendentale vlak 'n teoretiese abstraksie raak te sien wat wesenlik menswees beïnvloed. Dit is juis hierdie abstrakte dimensie wat soos 'n "heilige koepel", ofte wel 'n simboliese universum, op 'n dialektiese wyse "kultuur" in die sosiale universum daarstel, want die sosiale wêreld waar kultuur beoefen word, spruit voort uit, word gevorm en gedryf deur die simboliese wêreld. So gesien, is kultuur die dimensie wat bestaan uit die innerlike, onsigbare, teoreties-abstrakte aspekte

\footnotetext{
${ }^{12}$ Moderne soeke na "objektiewe kennis" en "die waarheid" het fondamentalisme (foundationalism) tot gevolg gehad (kyk Moser [1995] 1999:321-323; Murphy \& McClendon 1988-1989:192-193; Thiel 1994:17-19, 82-84, 87-88, 94-97; Guardino 1989:241-252; 1990:221-235; 1995/96:57-69) Fondamentalisme kan soos volg beskryf word (Burkhard 2004:132): "[F]oundationalism refers to absolutely irreducible principles of knowledge and action whose truth imposes itself with irrefutable evidentiary power. They are 'first' principles, since nothing can precede them, and as such they are unquestioned". In die moderne wetenskap het die soeke na vaste kennis uitgeloop op die formulering van natuurwette en in die filosofie was die menslike rede die vertrekpunt. Later ontwikkelinge in die natuurwetenskap soos die kwantumfisika en Einstein se relatiwiteitsteorie, het die "vaste fondamente" geskud. In die filosofie kon die menslike rede ook nie by een absolute waarheid uitkom nie. Postmoderne denke het uitgewys dat enige vorm van fondamentele beginsels eintlik onhoudbaar is.

${ }^{13}$ Kyk veral Johann Beukes [2008], Voices carry: An archaeology of the Hervormd approach, vir publikasie in HTS 64(1\&2).
} 
van die menswees van individue wat op intersubjektiewe, kollektiewe wyse hulle persoonlikhede en waardes met ander persone deel.

Volgens hierdie siening word aspekte soos dit wat mense werklik doen en hoe hulle fisies optree, die strukture en instellings wat mense vorm en die fisiese interaksie tussen mag en faktore soos geld of beroepstatus nie as kultuur gereken nie. Laasgenoemde aspekte het met alleen die materiële aspekte van die lewe te doen wat die spirituele aspekte daarvan uitsluit. Dit kom op 'n digotomie neer en kan as die produk van Plato se klassieke dualisme beskou word. Hiervolgens word die liggaam en die gees van mekaar geskei en in die moderne era het hierdie skeiding veroorsaak dat kultuur, dit wil sê die abstrakte religie deur sekere intellektueel bewuste persone in Europa verag is omdat dit as is deel van die onwerklikheid van bestaan en dus as nie-wetenskaplik gereken is. So byvoorbeeld het Baron d'Holbach (1723-1789) religie, met verwysing na die Judaïsme en Christendom, beskou as 'n hoogs "aansteeklike siekte", wat uit angs gespruit het en deur "tiranne" en "priesters" vertroetel is, mense wat die "siek verbeelding" van die massas uitgebuit het (Baron d'Holbach, in Dennis C Duling 1979:40).

Dialektiese denke het klassieke dualisme egter in 'n hersiene vorm 'n nuwe rigting laat inneem, sodat die mensewêreld in die sosiale wetenskappe gesien is as tegelykertyd verdeel tussen en verweef as die (objektiewe) waarneembare sosiale wêreld en die (subjektiewe) wêreld van denke en ervaring. Die "nuwe" rigting het 'n revolusie in epistemologie ingelui. Filosofies gesien, was dat Immanuel Kant ${ }^{14}$ (1724-1804) wat vir hierdie kenteoretiese revolusie verantwoordelik was.

Kant het die eensydigheid van die sogenaamde "objektiewe wetenskaplike" benadering as produk van die positiwisme ingesien. ${ }^{15} \mathrm{Hy}$ het daarop gewys dat objekte aan die kennende subjek verskyn na gelang van die vrae wat die subjek self wil vra. Daarom het Kant onderskei tussen die wetenskaplike (sintuiglike) wêreld (deur Peter Berger ${ }^{16}$ die sosiale universum

\footnotetext{
${ }^{14}$ Kyk J Lauster (2004), Prinzip und Methode: Die Transformation des protestantischen Schriftprinzips durch die historische Kritik von Schleiermacher bis zur Gegenwart, veral bls 27-29. Tübingen: Mohr Siebeck. (Hermeneutische Untersuchungen.)

${ }^{15}$ Die rasionalisme vorm die grond van die positiwisme. Volgens die positiwisme kan kennis (insluitende dié van die metafisika) alleen bekom word deur empiriese waarneming.

${ }^{16}$ Werke van Peter Berger wat invloedryk is, is The noise of solemn assemblies: Christian commitment and the religious establishment (1961), The precarious vision: A sociologist looks at social fictions and the Christian faith (1961), The social construction of reality (1967; uitgegee saam met sy student Thomas Luckmann as mede-outeur), The sacred canopy: Elements of a sociological theory of religion (1967), A rumor of angels: Modern society and the rediscovery of the supernatural (1970), The heretical mind (1979), The other side of God (1980), The desecularization of the world: Resurgent religion and world politics (1999), The limits of social cohesion (1999), Redeeming laughter: The comic dimension of the human experience (1997), Many globalizations: Cultural diversity in the modern world (2002), and Questions of faith: A sceptical affirmation of Christianity (2004).
} 
genoem) en die (nie-geobjektiveerde) wêreld (deur Peter Berger die simboliese universum genoem). Volgens Immanuel Kant is die "postulate" soos God en oneindigheid deel van die "simboliese universum". Onder hierdie "postulate" hoort ook die mens se "affektiewe ervarings" soos vreugde, bedroefdheid, hoop, skaamte, plotselinge skrik en ontsetting, angs en bangwees, verwondering en verbasing, lag, huil, woede, vertroue (d w s geloof) en liefde. Die geobjektiveerde sintuiglike wêreld is kenbaar op grond van die "teoretiese rede" en die nie-geobjektiveerde wêreld van ervaring op grond van die "praktiese rede". As deel van die sintuiglike, eindige wêreld is die mens aan natuurlike kousaliteit en verganklikheid onderwerp, hoewel die mens die plig en die vryheid daartoe het om die goeie ter wille van die goeie te doen.

Hierdie kenteoretiese revolusie het vir die teologie en eksegese ingrypende implikasies ingehou deurdat die dialektiek 'n "derde opsie" tussen Ortodoksie en Liberale teologie moontlik gemaak het. Belangrike eksponente was Rudolf Bultmann ${ }^{17}$ en Karl Barth. ${ }^{18}$ Op die gebied van die sososiologie was Marx, Weber en Durkheim invloedryke voorstaanders van die dialektiese denke. Karl Marx (1818-1883) het die Platoniese dualisme verwerp en tog kultuur steeds in negatiewe lig bejeën. Volgens hom het dit daardie aspek van die "superstruktuur" verteenwoordig wat dialekties onderskei behoort te word van die waarneembare sosiale "infrastruktuur" wat as tussenganger optree tussen produksie en interaksie. Ook Max Weber (1864-1920) het ook die klassieke tweespalt tussen liggaam en gees verwerp, maar het kultuur meer belangrik geag, alhoewel hy dit steeds beperk het tot die sfeer van "geestelike moraliteit" wat onderskei moet word van konkrete sosiale organisasie in klasse, die staat en tegnologie. By Emile Durkheim (1858-917) kry ons die beklemtoning van die rol van van kultuur as gedeelde waardes, soms gevorm soms misvorm deur die abstrakte, transendentale numinieuse kragte wat weerspieël word wanneer 'n mens die magsverhoudings in die samelewing in oënskou neem. Talcott Parsons (1902-1979) het 'n soortgelyke rigting

\footnotetext{
${ }^{17}$ Kyk R Bultmann ([1933a] 1993), Die Bedeutung der "dialektischen" Theologie für die neutestamentliche Wissenschaft, in Glauben und Verstehen: Gesammelte Aufsätze, Erster Band, 114-133; (1933d] 1993); Die liberale Theologie und die jüngste theologische Bewegung, in Glauben und Verstehen: Gesammelte Aufsätze, Erster Band, 1-25;

${ }^{18}$ Kyk K Barth ([1924] 1966), Biblische Fragen, Einsichten und Ausblicke, in Moltmann, J (Hrsg), Anfänge der dialektische Theologie, Teil 1: Karl Barth. Heinrich Barth. Emil Brunner, 49-76; (1925a), Das Schriftprinzip der reformierte Kirche. ZZ 3, 215-245; ([1925b] 1966), Das Wort Gottes als Aufgabe der Theologie, in Moltmann, J (Hrsg), Anfänge der dialektische Theologie, Teil 1: Karl Barth. Heinrich Barth. Emil Brunner, 197-218; (1925c), Die neue Welt in der Bibel, in Das Wort Gottes und die Theologie, 18-32.
} 
ingeslaan toe hy 'n dialektiese onderskeid getref het tussen die "kulturele stelsel" (kollektiewe waardes) en die "sosiale stelsel" (menslike interaksie). ${ }^{19}$

Dit was dus dialektiese denke in die filosofie, teologie en sosiologie wat gelei het tot die siening dat elke "definisie" van die konsep van "kultuur" as relatief gesien behoort te word. Wat as kultuur vestaan moet word, is relatief tot ' $n$ bepaalde periode, denkraamwerk en wetenskaplike oogpunt. Gesien vanuit Peter Berger se kennissosiologiese perspektief is kultuur daardie onomskrewe, moeilik beskryfbare dimensie van menswees wat betrekking het op denke, houdings, emosies, waardes en die lewenspatrone en geloofspatrone op ' $n$ abstrakte vlak wat in menslike interaksie uiting vind binne die raamwerk van die kollektiewe strukture wat 'n ekonomiese, politieke, familiale en religieuse karakter het. Op hierdie manier beskou, verteenwoordig kultuur 'n determinatiewe krag wat geen mens kan ontsnap nie. Die determinasie gaan verder as die empiriese sosiale wêreld waarin mense leef; juis omdat dit die sosiale wêreld is wat dialekties geaffekteer word deur 'n "heilige koepel" wat die simboliese wêreld uitmaak en wat die lewens van individue en hulle gedeelde omgewing beïnvloed.

Dit is binne hierdie konteks waar 'n mens op die gebied van die teologie met die godsdienstige verskynsel van die mistifisering van sosiale gebruike te doen kry. Mistifikasie is onlosmaaklike deel van sosialisering. Deel van hierdie proses is om norme as lewensriglyne te internaliseer. Gesosialiseerde norme raak maklik geyk en waar dit bydra om sosiale identiteit te skep, kry kultuurgebruike dikwels 'n primordiale status deurdat dit as goddelik gesanksioneer word. Hoewel die mens as deel van die sintuiglike, eindige wêreld aan natuurlike kousaliteit en verganklikheid onderwerp is (kyk die insig van Immanuel Kant waarna hierbo verwys is), kry sekere sosiale norme op hierdie wyse ewige geldigende waarde. Hierdie verskynsel word veral aangetref in "boekgodsdienste" - soos Judaïsme, Islam en die Christendom omdat dié norme nie net as geopenbaarde waarhede vanuit die "heilige koepel" geag word nie, maar ook as geïnkodeer in "heilige skrifte".

Soos alle ander mense, is Christene dus ook aan hierdie dialektiese kousaliteit gebind. Met mistifikasie word gevolglik bedoel dat sekere kultuurgebruike gelyk gestel word aan "God se wil", veral waar sosiale identiteit met religieuse identiteit gemeng word. ${ }^{20}$ Uit 'n teologiese oogpunt

\footnotetext{
${ }^{19} \mathrm{Kyk}$ die bespreking hiervan deur Wuthnow et al (1987) wat fokus op vier perspektiewe in die hedendaagse Europese filosofie: fenomenologie, kulturele antropologie, strukturalisme, en kritiese teorie.

${ }^{20}$ Byvoorbeeld, daar waar kinders van biologiese ouers deur die ouers gedoop word om so lidmate van die kerk te word. Dit wil sê, sosiale identiteit (kinders van biologiese ouers) word tegelyk 'n religieuse identiteit (kinders van God en lidmate van 'n geloofsgemeenskap) - en "kerk" en "verbond" en "volk" word uitruilbare begrippe.
} 
word sulke gemistifiseerde kultuurgebruike gesien as deel van die "skeppingsorde". So 'n "skeppingsordening" word dan selfs beskou as 'n "goddelike" natuurimperatief. Die verhouding tussen mense en kultuur is derhalwe in ' $n$ sekere $\sin$ 'n kwessie van "determinasie", of eerder 'n verhouding wat aan alledaagse situasies en lewenspatrone gebonde is.

'n Kultureel-kritiese benadering in Christelike teologie is egter ' $n$ disposisie wat dit betwyfel dat ' $n$ betekenisvolle lewe afhang van ' $n$ Christen se aanvaarding van en konformiteit met sogenaamde skeppingsordes as goddelike dwingendhede. Peter Berger verwys na so 'n blinde onderdanigheid aan kultuur met betrekking tot geloofsaspekte as bad faith. Omdat die dialektiese teoloog dus raaksien dat sodanige onderdanigheid aan gemistifiseerde natuurimperatiewe Bybels gelegitimeer word as God se wil, wil die dialektiese teoloog deur middel van kultuurkritiek ruimte skep vir alternatiewe denke wat die tradsionele en konvensionele nie sondermeer as "goddelik" aanvaar nie maar, inteendeel, tradisies ondersoekend bevraagteken.

Dialektiese denke het dus die weg voorberei vir die toepassing van kritiese teorie in die geesteswetenskappe en vir die hermeneutiek van suspisie in die teologie en Bybelwetenskap. Dit is spesifiek in sy boek, $A$ rumor of angels, dat Berger (1970) 'n pleidooi lewer vir 'n kritiese teorie wat neerkom op die verwelkoming van die so genoemde "lewende, bewegende rustelose krag" (living, moving restless power). Hierdie kritiese disposisie het Paul Tillich (1948:163) die "Protestantse beginsel" genoem (kyk Berger 1970:84-85). Dit is die beginsel wat onderliggend is aan die Protestantse tradisie se kritiese perspektief en waarna Tillich ${ }^{21}$ verwys het as die "moed van Protestantisme" (Mut des Protestantismus). Hierdie waagmoed spruit voort uit 'n bewustheid wat Jean Paul Sartre ${ }^{22}$ die "vloek van die gewete" genoem het (in Frans: le malheur de la conscience). Sartre het dit le malheur de la conscience genoem omdat sekere keuses van mense misleidend voorgestel word as 'n noodlot waaraan mense uitgelewer is. Die euwel (ofte wel die "vloek") is dat mense nie aan hulle gewete erkenning verleen dat dit hulleself is - en nie kragte ekstern aan die mens nie - wat mense gebring het om self in eie persoon bepaalde keuses al dan nie te gemaak het (vgl Berger 1970:78).

Die waagmoed van die Protestantse geloof is om die feilbaarheid van die mens eie prestasie en vermoë so ruiterlik te erken, dat hy of sy self-krities daarmee kan omgaan met die doel om menswees se absolute vertroue op God alleen te plaas. Natuurlike verburgerlikte teologie het die verleiding om hierdie self-kritiese waagmoed van "gewete ontbloting" en die erkenning van

\footnotetext{
${ }^{21}$ Paul Tillich (1987), Systematische Theologie, II, veral bl 118, in Jörg Lauster (2004:329).

22 Jean Paul Sartre (1946), L'existentialisme est un humanisme, in W Banning (1969:155158).
} 
die neiging tot bad faith te ontsnap deur 'n te positiewe premie en vertroue op menslike denke en dade te plaas. Wanneer hierdie kulturele denke en dade ongesiens en selfs onbewus die vorm van gemistifiseerde religieuse ideologie aanneem, het die mens stil-stil die beoefenaar van natuurlike verburgerlikte teologie geword.

Peter Berger, geïnspireer deur die gees van Protestantse waagmoed, het, soos Karl Barth vroeër, ${ }^{23}$ 'n onderskeid tussen religie en geloof getref. Met "religie" bedoel hy gemistifiseerde kultuur. Geloof is absolute vertroue in God. ${ }^{24}$ Maar religie is iets anders. As die masker van godsdienstigheid ontbloot word, kry jy niks meer as 'n geakkultureerde oriëntasie ten opsigte van tradisies nie. Volgens Peter Berger (1970:82) moet alle tradisies daarom bevraagteken word in die soeke na tekens van transendensie wat in die tradisie gesedimenteer kan wees. Vir Berger (1970:82) beteken dit 'n benadering wat gegrond is in empiriese ondersoekmetodes (en die mees belangrike, natuurlik, in die metodes van moderne historiese ondersoek) en vry van dogmatiese apriories ( $\mathrm{d}$ w s, vry van dogmatiese aannames gegrond in neo-ortodokse konfessionele "foundationalist" teologie). ${ }^{25}$

Die ideaal wat volgens Berger behoort te herleef in hedendaagse teologie en in die Christelike geloofsgemeenskap, is wat hy tereg die "Schleiermacher-era" noem. ${ }^{26}$ Hierdie "era" verteenwoordig 'n toleransie wat ruimte skep vir kreatiewe innovering en oop is vir die moontlkheid dat die sinvolheid van menslike bestaan weer en weer kan realiseer - veral

\footnotetext{
${ }^{23}$ Kyk onder andere Barth, K 1957, Schicksal und Idee in der Theologie, in Theologische Fragen und Antworten, 54-92, veral bls 85-87. Zollikon: Evangelischer Verlag. Vergelyk ook Zahrnt ([1966] 1967), Die Sache mit Gott: Die protestantische Theologie im 20. Jahrhundert, veral bl 141.
}

${ }^{24}$ Kyk die insigte van Friedrich Schleiermacher, soos bespreek deur onder andere Schröder, M 1996. Die kritische Identität des neuzeitliche Christentums: Schleiermachers Wesensbestimmung der christliche Religion. Tübingen: Mohr Siebeck. (BHTh 96.)

${ }^{25}$ Kyk veral Berger, P L 2004. Questions of faith: A skeptical affirmation of Christianity. Malden, MA: Blackwell Publishing. (Religion in the Modern World.)

${ }^{26}$ Rudolf Bultmann se "dialektiese hermeneutiek" is een van die belangrikste produkte van die Schleiermacher-erfenis. So byvoorbeeld het Bultmann se gebruik van die uitdrukking die "intensie van 'n mite" 'n soortgelyke bedoeling as dié wat Peter Berger (én Schleiermacher se idee van "gevoel van absolute afhanklikheid" [= schlechthinnige Abhangigkeit] as uitdrukking van gottglaubige Selbstbewußtsein) in gedagte het. Vir Bultmann kom die interpretasie van die saak waaroor die Nuwe Testament dit het, neer op ontmitologisering en op die eksistensiale toe-eiening van hierdie saak, ofte wel die "intensie van mite". Volgens Bultmann het ons in die Bybel, en daarom ook in die Nuwe Testament, met ' $n$ ou en mitiese wêreldbeeld te make het soos byvoorbeeld dat die wêreld uit drie verdiepings naamlik hemel, aarde en onderwêreld bestaan. Die Bybel wil egter nie hierdie wêreldbeeld op ons afforseer nie en daarom moet ons vra na wat met hierdie beeld bedoel is. Dit kan gedoen word deur ontmitologisering. Met ontmitologisering word dus niks anders beoog as om die bedoeling van die mite of mitiese spreekwyse duidelik te maak nie, dit wil sê die bedoeling daarvan om iets van die menslike eksistensie te sê (kyk Bultmann, R [1941] 1988. Neues Testament und Mythologie: Das Problem der Entmythologisiering der neutestamentliche Verkündigung. Nachdruck der 1941 erschienen Fassung, hrsg von E Jüngel. München: Chr Kaiser Verlag; Bultmann, R 1952. Das Problem der Entmythologisierung, in Bartsch, H W (Hrsg), Kerygma und Mythos, Bd 2, 179-208. Hamburg: Reich \& Heidrich, Evangelischer Verlag). 
aangesien hierdie teenswoordige en toekomstige ervaring eksistensiaal één word (kongeniaal is) met ervarings van vorige geslagte gelowiges en daarom toeganglik is vir historiese ondersoek. Vanuit die narratiewe van die verlede, spesifiek daardie narratiewe ingebed in lewens van profete en apostels, waarvan Jesus s'n self die hoeksteen en fondament is, kan die onafgehandelde toekomstige taak van evangelisasie verdere impetus kry. Waar die evangelie van die koninkryk van God verkondig word, word waardes geleef wat anders is as waar mense sonder God heers. Met evangeliese waardes word die las van menslike vermoeidheid as gevolg van intermenslike konflik verlig. Hierdeur word die las van spanning oorkom spanning as gevolg van 'n onversoende verhouding met God met gevolglike distorte en verwronge verhoudings tussen mense vanweë die anderswees in nasionaliteit, sosiale lokaliteit (land en taal), gender, ras, geslagtelikheid, spiritualiteit en sosiale ongelykheid. Dit is die gees van die Schleiermacherera wat ons help om die dialektiese spanning tussen kultuur en geloof te verstaan.

Deel van hierdie proses is om in te sien dat absolute geloof in God iets verg wat net deur genade as Goddelike gawe moontlik word, te wete om op paradoksale wyse vry van gebondenheid aan wêreldsheid te word - in Pauliniese sin, vry van die slaverny aan sonde as 'n demoniese mag. Die nastreef van hierdie vryheidsideaal, die propagering daarvan en die uitleef daarvan, vra egter ' $n$ prys om te betaal. Kultuurkritiek eis baie van die gelowige.

In sy bydrae oor "kultuurkritiek" in A K M Adam se versameling Handbook on postmodern biblical criticism, skryf Kenneth Surin (2000:49-54) dat 'n doeltreffende kultuurkritiek vir teologie een sal wees wat saamval met die Nuwe-Testamentiese verkondiging oor die wyse waarop verlossing verkry kan word. So gesien, kan kultuurkritiek vanuit 'n evangeliese perspektief 'n bydrae maak deur die siening dat gelowiges, hoewel in die wêreld, tog nie van die wêreld is nie. Hierdie perspektief realiseer egter nie sonder spanning nie, want daar is ' $n$ basiese onwilligheid om die absolute vryheid te omhels omdat historiese toestande dikwels in die weg staan van die nastrewing van vryheid. Die prys wat betaal word, is ook hoog.

Surin (2000:149-54) stel dit soos volg: "[l]t is always possible that the bringers of redemption will be forced out of sight by a history that cannot have any place for them. Such redemptive and utopian propensities will be hidden and marked by untimeliness as well as being discontinuous with the course of history ...." Hierdie "prys" is betaal deur profete, deur Jesus, en deur apostels soos Paulus. Bybelse narratiewe vertel hoe historiese omstandighede in Bybelse tye daartoe gelei het dat die "bringers van verlossing" gemarginaliseer is as gevolg van die oënskynlike "ontydigheid" van hulle 


\section{Sosiaal-wetenskaplike kritiese eksegese van Nuwe-Testamentiese tekste}

kultuurkritiek. Jesus se sterwe aan 'n kruis staan in hierdie verband uit. Vir Christene het sy kruisdood nie net as aansporing gedien om self hulle eie kruis ter wille van Jesus en Jesus se evangelie (Mark 8:38) te dra nie; dit het soteriologiese krag gekry deurdat dit as 'n versoeningsdood verkondig is wat die offerritueel in die Israelse tempelgodsdiens verplaas het.

Lucien Legrand (2000:111-112) beskryf Jesus se kultuurkritiek op 'n treffende wyse. Volgens hom was Jesus se lewe, dade, denke en taal geheel en al gewortel in die Joodse kultuur. Volgens Legrand kan Jesus se deelhê aan kultuur nie so eenvoudig met moderne begrippe soos "inkulturasie" of "akkulturasie" beskryf word nie. Ook die term "kontekstualisering" kan Jesus se betrokkenheid by kultuur nie adekwaat kommunikeer nie. Die werkwoordelike frase "-isering" in die term "kontekstualisering" skep die indruk van 'n kunsmatige poging asof Jesus doelbewus sou gepoog het om deel van die Joodse konteks te wees. In Jesus se geval was daar geen sodanige poging nie. Sy kultuur was sy eksistensie.

Niks van Jesus se lewe was geforseerd of kunsmatig nie. Hy was eenvoudig kind van sy tyd en tot sy geboorteland behoort en aan daardie land se kultuur deelgeneem op 'n spontane manier. Tog vind ons by Jesus 'n spanning - selfs 'n bipolariteit - tussen sy rol as "profeet" ${ }^{27}$ aan die een kant eintlik as "Seun van God" volgens Matteus 16:16 - en sy konformiteit aan kultuur aan die ander kant. Hierdie spanning het inderdaad van Jesus 'n "marginale Jood" gemaak. Hy het buite die binnekring van die gevestigde Joodse tempelkultuur gestaan. Hy het nie ingepas by enige van die konvensionele rolle in die kultuur van sy voorgeslagte nie - ook nie in die rol van "profeet" volgens Markus 8:28 nie. Inteendeel, as Jesus Homself hoegenaamd met een van die sosiale groepe en sy tyd vereenselwig het, was dit met die "armes van die land". Hy het gedeel in hulle lewe, hulle taal gepraat, tuis gevoel met hulle tipe wysheid - soos duidelik gesien kan word in die metafore uit hulle alledaagse wêreld wat Hy in sy gelykenisse gebruik het.

In daardie sin was Jesus dus nie eintlik 'n "marginale Jood" nie, aangesien die "mense van die land" die meerderheid van die Palestynse bevolking uitgemaak het. Maar ook wat hierdie konteks betref, kan 'n mens Jesus nie werklik in 'n netjiese boksie plaas nie. Die feit dat die meeste van die gewone mense nie werklik in lyn was met die hoofstroming in Joodse denke nie, was hoofsaaklik as gevolg van die feit dat hulle nie vir hierdie hoofstroom so omgegee het dat hulle hulle daarmee met hart en siel sou vereenselwig nie. By Jesus kry ons egter nie so 'n onverskilligheid nie. Inteendeel, die feit dat Jesus nie in lyn daarmee was nie, is 'n uiting van 'n

\footnotetext{
${ }^{27}$ Kyk PhD-proefskrif van Estelle H Dannhauser, "Jesus the prophet: Maps and memories", Universiteit van Pretoria, 2006.
} 
meer radikale toewyding aan God en sy hartsgrondelike verbintenis tot die saak wat Hy die "evangelie van die koninkryk van God" genoem het (en Paulus in Gal 2:14, die "waarheid van die evangelie"). In kort: Jesus verras ons deur by mense betrokke te raak vir wie die samelwing nie ruimte wou bied nie.

Kan ons in die lig van hierdie "verrassing" sê dat Jesus 'n "anti-kultuur" of selfs 'n "teen-kultuur" houding gehad het? Miskien is daar aspekte in sy lewe wat daarop dui dat Jesus ongetwyfeld 'n andersgesinde was! En tog laat die woord "teen-kultuur" nie reg geskied aan die visie wat Jesus ten opsigte van die "nuwe Israel" gehad het nie. Die begrip "teen-kultuur" dui op 'n antitese en skep die indruk dat jy die rol van kultuur wil ontken. Jesus se houding het nie 'n teen-kultuur weerspieël nie. Dit was eerder 'n houding van integrale vryheid. Van binne uit die kultuur waaraan Jesus behoort het en waarin Jesus gebore is, oorstyg Jesus beide die kulturele en die teenkulturele patrone van sy tyd - integraal deel van kultuur, maar terselfdertyd vry daarvan!

Streng gesproke, gesien vanuit die mensheidsgeskiedenis, behoort Jesus tot 'n groep mense wat nuwe dimensies vir menslike eksistensie open soos digters wat "nuwe tale" met hulle skryfwerk skep; soos geïnspireerde profete en Gees-vervulde heilige mense wat so deel het aan die sfeer van God, dat dit gewone menslikheid oorskry, omdat hulle ontmoeting met die goddlike ver bó die van die alledaagse is. Diesulkes is ongetwyfeld mense van hulle eie tyd en tog gee hulle taal uiting aan die uitdrukkkings van die kultuur van hulle land. Maar hulle oorstyg dit en hulle word, te midde van hulle eie generasies, die ontdekkingsreisigers van nuwe horisonne van menswees. En dit was Jesus! Kultuurkrities in die ware sin van die woord! Wanneer Jesus (in Mark 8:38) sy volgelinge oproep om nie skaam te wees om hulle met sy woorde - sy evangelie - te vereenselwig nie, dan roep Jesus ons op tot kultuurkritiek.

\section{Literatuurverwysings}

Barth, K [1924] 1966. Biblische Fragen, Einsichten und Ausblicke, in Moltmann, J (Hrsg), Anfänge der dialektische Theologie, Teil 1: Karl Barth. Heirich Barth. Emil Brunner, 49-76. 2.Aufl. München: Chr Kaiser Verlag. (TB17/1.)

Barth, K 1925a. Das Schriftprinzip der reformierte Kirche. Zwischen den Zeiten 3, 215-245.

Barth, K [1925b] 1966. Das Wort Gottes als Aufgabe der Theologie, in Moltmann, J (Hrsg), Anfänge der dialektische Theologie, Teil 1: Karl Barth. Heirich Barth. Emil Brunner, 197-218. 2. Aufl. München: Chr Kaiser Verlag. (TB17/1.)

Barth, K 1925c. Die neue Welt in der Bibel, in Das Wort Gottes und die Theologie, 18-32. München: Chr Kaiser Verlag. 
Barth, K 1957. Schicksal und Idee in der Theologie, in Theologische Fragen und Antworten, 54-92. Zollikon: Evangelischer Verlag.

Berger, K 1977. Exegese des Neuen Testaments: Neue Wege vom Text zur Auslegung. Heidelberg: Quelle und Meyer.

Berger, P L 1961. The noise of solemn assemblies: Christian commitment and the religious establishment in America. Garden City, NY: Doubleday.

Berger, P L 1967. The sacred canopy: Elements of a social theory of religion. Garden City, NY: Doubleday.

Berger, P L 1970. A rumor of angels: Modern society and the rediscovery of the supernatural. Garden City, NY: Doubleday. (Anchor Books.)

Berger, P L 2004. Questions of faith: A skeptical affirmation of Christianity. Malden, MA: Blackwell. (Religion in the Modern World.)

Berger, P L \& Luckmann, T 1975. The social construction of reality: A treatise in the sociology of knowledge. Harmondsworth: Penguin.

Beukes, J [2008]. Voices carry: An archaeology of the Hervormd approach. HTS 64(1\&2). (Forthcoming.)

Bhaba, H 1994. The location of culture. London: Routledge.

Brandt, P-Y 2005. Erzählung und Identitätsbildung: Die Spiegelfunktion von Mk 12, 112 in der Konstruktion der Identität Jesu. EvTh 65(2), 135-147.

Brawley, R L 2003. Evocative allusions in Matthew: Matthew 5:5 as a test case. HTS 59(3), 597-619.

Bultmann, R [1933a] 1993. Die Bedeutung der "dialektischen" Theologie für die neutestamentliche Wissenschaft, in Glauben und Verstehen: Gesammelte Aufsätze, Erster Band, 114-133. Neunte Aufl. Tübingen: Mohr. (UTB 1760.)

Bultmann, R [1933d] 1993. Die liberale Theologie und die jüngste theologische Bewegung, in Glauben und Verstehen: Gesammelte Aufsätze, Erster Band, 1-25. Neunte Auflage. Tübingen: Mohr. (UTB 1760.)

Bultmann, R [1941] 1988. Neues Testament und Mythologie: Das Problem der Entmythologisiering der neutestamentliche Verkündigung. Nachdruck der 1941 erschienen Fassung, hrsg von E Jüngel. München: Chr Kaiser Verlag. (BevTh 96.)

Bultmann, R 1952. Das Problem der Entmythologisierung, in Bartsch, H W (Hrsg), Kerygma und Mythos, Bd 2, 179-208. Hamburg: Reich \& Heidrich, Evangelischer Verlag.

Burkhard, J J 2004. Apostolicity then and now: An ecumenical church in a postmodern world. Collegeville, MN: Liturgical Press. (Michael Glazier Book.)

Carter, W 2004. Going all the way? Honoring the Emperor and sacrificing wives and slaves in 1 Peter 2:13-3:6, in Levine, A-J \& Robbins, M M (eds), A feminist companion to the Catholic Epistles and Hebrews, 14-33. London: T\&T Clark.

Craffert, P F 1991. Towards an interdisciplinary definition of the social-scientific interpretation of the New Testament. Neotestamentica 25(1), 123-144.

Craffert, P F 1997. The stuff world-views are made of. Scriptura 61, 193-212.

Craffert, P F 2001. Jesus van Nasaret as historiese figuur: Die rol van wêreldbeelde en interpretasiestyle. Fragmente 7, 101-115.

Craffert, P F 2001. An exercise in the critical use of models: The "goodness of fit" of Wilson's sect model, in Pilch, J J (ed), Social scientific models for interpreting the Bible: Essays by the Context Group in honour of Bruce J Malina, 21-46. Leiden: Brill. 
Dannhauser, E H 2006. Jesus the prophet: Maps and memories. PhD dissertation, University of Pretoria.

Duling, D C 1979. Jesus Christ through history. New York: Harcourt Brace Jovanovich.

Duling, D C 2005. Empire: Theories, methods, models, Riches, J \& Sim, D C (eds), The Gospel of Matthew in its Roman imperial context, 49-74. London: T \& T Clark. (Early Christianity in Context. JSNTSS 276.)

Elliott, J H 1991. Temple versus household in Luke-Acts: A contrast in social institutions, in Neyrey, $\mathrm{J} \mathrm{H}(\mathrm{ed})$, The world of Luke-Acts: Models for interpretation, 211-240. Peabody, MA: Hendrickson.

Elliott, J H 1993. What is social-scientific criticism? Minneapolis, MN: Fortress. (Guides to Biblical Scholarship.)

Esler, P F 2005a. Social scientific models in biblical interpretation, in Esler, P (ed) Ancient Israel: The Old Testament in its social context, 3-14. Minneapolis, $\mathrm{MN}$ : Fortress.

Esler, P F 2005b. The Context Group Project: An autobiographical account, in Lawrence, L J \& Aguilar, M I (eds), Anthropology \& biblical studies: Avenues of approach, 46-61. Leiden: Deo.

Fann, K T 1970. Peirce's theory of abduction. The Hague: Nijhoff.

Garrett, S 1992. Sociology of early Christianity, in Freedman, D N (ed), Anchor Bible Dictionary, vol 6, 89-99. New York: Doubleday.

Giddens, A 1984. The constitution of society: Outline of the theory of structuration. Cambridge: Polity.

Groenewald, J 2005. Baptism, Eucharist, and the earliest Jesus-groups - from the perspective of alternate states of consciousness. DD-proefskrif, Universiteit van Pretoria.

Guardino, T G 1990. Revelation and foundationalism: Toward hemeneutical and ontological appropriateness. Modern Theology 6, 221-235.

Hoefnagels, H [1974] 1976. Kritische sociologie: Inleiding tot het sociologisch denken der "Frankfurter Schule". 2e druk. Alphen aan den Rijn: Samson Uitgeverij. (Sociaal Politieke Verkenningen.)

Holmberg, B 1990. Sociology and the New Testament: An appraisal. Minneapolis, $\mathrm{MN}$ : Fortress.

Horrell, D G 1999. Introduction: Social-scientific interpretation of the New Testament: Retrospect and prospect, in Horrell, D G (ed), Social-scientific approaches to New Testament interpretation, 3-27. Edinburgh: T \& T Clark.

Horrell, D G 2005. Social-scientific interpretation thirty years on: Prospect (and retrospect). Paper presented at the Social Scientific Criticism section of the Society of Biblical Literature Meeting at Philadelphia (PA) on Sunday, November 20, 2005.

Immink, F G 2003. In God geloven: Een praktisch-theologische reconstructie. Meinema: Zoetermeer.

Legrand, L 2000. The Bible on culture: Belonging or dissenting? Maryknoll, NY: Orbis.

Lenski, G 1966. Power and privilege: A theory of social stratification. New York: McGraw-Hill.

Lenski, G 1970. Human societies: A macrolevel introduction to sociology. New York: McGraw-Hill. 
Lenski, G, [Lenski, J \& Nolan P] [1970] 1991. Human societies: An introduction to macrosociology. 6th edition. New York: McGraw-Hill.

Lenski, G, [Lenski, J \& Nolan P] [1970] 1995. Human societies: An introduction to macrosociology. 7th edition. New York: McGraw-Hill.

Maier, H O 2005. A sly civility: Colossians and Empire. JSNT 27, 323-349.

Malina, B J 1989. Dealing with biblical (Mediterranean) characters: A guide for US consumers. BTB 19(4), 127-141.

Malina, B J [1989] 1996. Christ and time: Swiss or Mediterranean?, in The social world of Jesus and the Gospels, 179-214. London: Routledge. (Original version published in $C B Q 51,1-31$.

Malina, B J 1991a. Is there a circum-Mediterranean person?: Looking for stereotypes. BTB 22(2), 66-87.

Malina, B J 1991b. Reading theory perspective: Reading Luke-Acts, in Neyrey, J H (ed), The social world of Luke-Acts: Models for interpreatation, 3-23. Peabody, MA: Hendrickson.

Malina, B J 1996. The social world of Jesus and the Gospels. London: Routledge.

Malina, B J \& Neyrey, J H 1991. First century personality: Dyadic, not individualistic, in Neyrey, J H (ed), The social world of Luke-Acts: Models for interpretation, 25-66. Peabody, MA: Hendrickson.

Malina, B J \& Rohrbaugh, R L 1992. Social-science commentary on the Synoptic Gospels. Minneapolis, MN: Fortress.

Martin, D B 1993. Social-scientific criticism, in McKenzie, S L \& Haynes, S R (ed), To each its own meaning: An introduction to biblical criticism and their application, 103-119. Louisville, KY: Westminster.

Moser, P K [1995] 1999 s v Foundationalism. The Cambridge Dictionary of Philosophy, 321-323.

Murphy, N 1990. Theology in the age of scientific reasoning. Ithaca, NY: Cornell University Press.

Murphy, N \& McClendon, J W 1988-1989. Distinguishing modern and postmodern theologies. Modern Theology 5, 191-214.

Ochs, P 1988. Peirce, pragmatism and the logic of scripture. Cambridge: Cambridge University Press.

Petersen, N R 1985. Rediscovering Paul: Philemon and the sociology of Paul's narrative world. Philadelphia, PA: Fortress.

Petersen, N R 1993. The Gospel of John and the sociology of light: Language and characterization in the fourth gospel. Valley Forge, PA: Trinity Press International.

Punt, J 2001. The New Testament, theology and imperialism: Some postcolonial remarks on Beyond New Testament theology. Neotestamentica 35(1-2), 120145.

Punt, J 2002a. From rewriting to rereading the Bible in postcolonial Africa:

Considering the options and implications. Missionalia 30(3), 410-442.

Punt, J 2002b. Empire, Messiah and violence: A contemporary view. Scriptura 80, 259-274.

Punt, J 2002c. Towards a postcolonial reading of freedom in Paul, in Ukpong, J S et al (eds), The Bible in the global village: Cape Town, 125-149. Atlanta, GA: Scholars Press. (Global Perspectives on Biblical Scholarship Series 3.) 
Punt, J 2003. Postcolonial biblical criticism in South Africa: Some mind and road mapping. Neotestamentica 37, 59-85.

Reilly, F E 1970. Charles Peirce's theory of scientific method. New York: Fordham University Press. (The Oresttes Brownson Series on Contemporary Thought and Affairs 7.)

Rhoads, D 1992. Social criticism: Crossing boundaries, in Anderson, J C \& Moore, S D (eds), Mark \& method: New approaches in biblical studies, 135-161. Minneapolis, MN: Fortress.

Robbins, V K 1996a. The tapestry of early Christian discourse: Rhetoric, society and ideology. London: Routledge.

Robbins, V K 1996b. Exploring the texture of texts: A guide to socio-rhetorical interpretations. Valley Forge, PA: Trinity.

Sartre, J P [1946] 1969. L'existentialisme est un humanisme, in Banning, W (red), Typen van zedeleer: Grepen uit de geschiedenis der niet in godsdienstig geloof gefundeerde ethiek, 155-158. Haarlem: De Erven F Bohn N V.

Schneider, L C 2000. Queer theory, in Adam, A K M (ed), Handbook of postmodern biblical interpretation. St Louis, MO: Chalice.

Schottroff, L 1990. Nicht viele Mächtige: Annäherungen an eine Soziologie des Urchristentums, in Befreiungserfahrungen: Studien zur Sozialgeschichte des Neuen Testaments, 247-256. München: Kaiser.

Scott, B B [1989] 1990. Hear then the parable: A commentary on the parables of Jesus. Minneapolis, MN: Fortress.

Scott, J C 1990. Domination and the arts of resistance. New Haven, CN: Yale University Press.

Schüssler Fiorenza, E 2002. Der wirkliche Jesus? - Fenistische Anfrage en die sozialwissenschaftliche Jesusforschung, in Stegemann, W, Malina, B J \& Theißen, G (Hrsg), Jesus in neuen Kontexten, 23-32. Stuttgart: Kohlhammer.

Segovia, F F 1998. Biblical criticism and postcolonial studies: Towards a postcolonial optic, in Sugirtharajah, R S (ed). The postcolonial Bible: Bible and postcolonialism, 1, 49-65. Sheffield: Sheffield Academic Press.

Segovia, F F 2000a. Decolonizing biblical studies: A view from the margins. Maryknoll, NY: Orbis.

Segovia, F F 2000b. Interpreting beyond borders: Postcolonial studies and diasporic studies in biblical criticism, in Segovia, F F (ed), Interpreting beyond borders: The Bible and postcolonialism, 3, 11-34. Sheffield: Sheffield Academic Press.

Segovia, F F 2000c. Reading-across: Intercultural criticism and textual posture, in Segovia, F F (ed), Interpreting beyond borders: The Bible and postcolonialism, 3, 59-83. Sheffield: Sheffield Academic Press.

Shin, I-C 2004. Matthew's inclusive community: A narratological and social-scientific reading. PhD dissertation, University of Pretoria.

Sugirtharajah, R S 1998a. Asian biblical hermeneutics and postcolonialism: Contesting the interpretations. (The Bible and liberation series.) Maryknoll, NY: Orbis.

Sugirtharajah, R S 1998b. Biblical studies after the Empire: From a colonial to a postcolonial mode of interpretation, in Sugirtharajah, R S (ed), The postcolonial Bible: The Bible and postcolonialism, 1, 12-22. Sheffield:Sheffield Academic Press. 
Sugirtharajah, R S 1998c. A postcolonial exploration of collusion and construction in biblical interpretation, in Sugirtharajah, R S (ed), The postcolonial Bible: The Bible and postcolonialism, 1, 91-116. Sheffield: Sheffield Academic Press.

Sugirtharajah, R S 1999. Thinking about vernacular hermeneutics sitting in a metropolitan setting, in Sugirtharajah, R S (ed), Vernacular hermeneutics: The Bible and Postcolonialism, 2, 92-225. Sheffield: Sheffield Academic Press.

Sugirtharajah, R S 2001. The Bible in the Third World: Precolonial, colonial, and postcolonial. Cambridge: Cambridge University Press.

Surin, K 2000. Culture/cultural criticism, in Adam, A K M (ed), Handbook of postmodern biblical interpretation, 49-54. St Louis, MO: Chalice.

Theissen, G 1974. Theoretische Probleme religions-soziologischer Forschung und die Analyse des Urchristentums. Neue Zeitschrift für systematische Theologie und Religionsphilosophie 16, 35-56.

Theissen, G [1975] 1979. Die soziologische Auswertung religiöser Überlieferungen: Ihre methodologischen Probleme am Beispiel des Urchristentums, in Studien zur Soziologie des Urchristentums, 35-54. Tübingen: Mohr. (WUNT 19.) [Oorspronklike weergawe het verskyn in Kairos 17(1975), 284-299.]

Theissen, G [1979] 1983. Studien zur Soziologie des Urchristentums. Tübingen: Mohr. (WUNT 19.)

Thiel, J E 1994. Nonfoundationalism. Minneapolis, MN: Fortress.

Tillich, P 1948. The Protestant era. Chicago, IL: University of Chicago Press.

Van Aarde, A G 2004b. Some thoughts on post-colonial hermeneutics and New Testament scholarship: Public lecture as visiting professor at the Evangelical Theological Seminary in Cairo (Egypt) on November 16, 2004. Reworked version of paper presented at the NRF Regional Conference "Shifting boundaries of knowledge - the role of social sciences, law and humanities", 28 May 2004, Tshwane University of Technology, Pretoria. Published in Afrikaans in 2004 as "Postmodern epistemology and postcolonial hermeneutics". HTS 60(3), 1105-1125.

Van Aarde, A G 2007a. Inleiding tot die sosiaal-wetenskaplike kritiese eksegese van Nuwe-Testamentiese tekste: Die metodologiese aanloop in die navorsingsgeskiedenis. HTS 63(1), 49-79.

Van Aarde, A G 2007b. Die sosiaal-wetenskaplike kritiese eksegese van NuweTestamentiese tekste: 'n Kritiese oorsig van die eerste resultate. HTS 63(2), 515-542.

Van der Ven, J A 1990. Entwurf einer empirischen Theologie. Kampen: Weinheim.

Van der Ven, J A 1993. Pastorale protocolanalyse, I: Pastoraat in vernieuwing. Praktische Theologie 5.

Van der Ven, J A 1994. Pastorale protocolanalyse, II: Pastoraat in maat en getal. Praktische Theologie 1.

Van der Ven, J A 1994. Pastorale protocolanalyse, III: Pastoraat naar zin en betekenis. Praktische Theologie 1.

Van Eck, E [1994] 1995. Galilee ad Jerusalem in Mark's story of Jesus: A narratological and social scientific reading. Pretoria; Promedia. (HTS Suppl 7.) ['n Hersiene weergawe van 'n DD-proefskrif, Universiteit van Pretoria, 1994.] 
Vledder, E-J [1994] 1997. Conflict in the miracle stories: A socio-exegetical study of Matthew 8 and 9. Sheffield: Sheffield Academic Press. (JSNS Series 152.) ['n Hersiene weergawe van 'n DD-proefskrif, Universiteit van Pretoria, 1991.]

Weber, M [1947] 1968a. Max Weber: On charisma and institution building. Selected papers edited and with an introduction by E N Eisenstadt. Chicago, IL: University of Chicago Press.

Weber, M 1949. Max Weber on the methodology of the social sciences, tr and ed by E A Shils \& H A Finch. Glencoe, IL: Free Press.

Weber, M 1962. Basic concepts in sociology, translated and introduced by H P Secher. London: Peter Owen.

Weber, M 1968b. Economy and society: An outline of interpretive sociology, Vol 1, ed by $\mathrm{G}$ Roth \& C Wittich. Berkeley, CA: University of California Press.

Woodson, L 1979. A handbook of modern rhetorical terms. Urbana, IL: National Council of Teachers of English. 